Article

\title{
From a Sequential Chemo-Enzymatic Approach to a Continuous Process for HMF Production from Glucose
}

\author{
Alexandra Gimbernat ${ }^{1}$, Marie Guehl ${ }^{2,3}{ }^{3}$, Nicolas Lopes Ferreira ${ }^{4}$, Egon Heuson ${ }^{1}$, \\ Pascal Dhulster ${ }^{1}{ }^{(0)}$, Mickael Capron ${ }^{2}$, Franck Dumeignil ${ }^{2}$ (D), Damien Delcroix ${ }^{3}$, \\ Jean-Sébastien Girardon ${ }^{2}$ and Rénato Froidevaux ${ }^{1, *}$ (iD \\ 1 Univ. Lille, INRA, ISA, Univ. Artois, Univ. Littoral Côte d'Opale, EA7394-ICV-Institut Charles Viollette, \\ F-59000 Lille, France; alexandra.gimbernat@gmail.com (A.G.); egon.heuson@univ-lille.fr (E.H.); \\ pascal.dhulster@univ-lille.fr (P.D.) \\ 2 Univ. Lille, CNRS, Centrale Lille, ENSCL, Univ. Artois, UMR 8181-UCCS-Unité de Catalyse et Chimie du \\ Solide, F-59000 Lille, France; guehl.marie@gmail.com (M.G.); mickael.capron@univ-lille.fr (M.C.); \\ franck.dumeignil@univ-lille.fr (F.D.); jean-sebastien.girardon@univ-lille.fr (J.S.G.) \\ 3 IFP Energies Nouvelles, Rond-point de l'échangeur de Solaize, BP 3, 69360 Solaize, France; \\ damien.delcroix@ifpen.fr \\ 4 IFP Energies Nouvelles, 1 et 4 avenue de Bois-Préau, 92852 Rueil Malmaison, France; \\ nicolas.lopes-ferreira@ifpen.fr \\ * Correspondence: Renato.froidevaux@univ-lille.fr; Tel.: +33-320-417-566
}

Received: 13 July 2018; Accepted: 27 July 2018; Published: 17 August 2018

\begin{abstract}
Notably available from the cellulose contained in lignocellulosic biomass, glucose is a highly attractive substrate for eco-efficient processes towards high-value chemicals. A recent strategy for biomass valorization consists on combining biocatalysis and chemocatalysis to realise the so-called chemo-enzymatic or hybrid catalysis. Optimisation of the glucose conversion to 5-hydroxymethylfurfural (HMF) is the object of many research efforts. HMF can be produced by chemo-catalyzed fructose dehydration, while fructose can be selectively obtained from enzymatic glucose isomerization. Despite recent advances in HMF production, a fully integrated efficient process remains to be demonstrated. Our innovative approach consists on a continuous process involving enzymatic glucose isomerization, selective arylboronic-acid mediated fructose complexation/transportation, and chemical fructose dehydration to HMF. We designed a novel reactor based on two aqueous phases dynamically connected via an organic liquid membrane, which enabled substantial enhancement of glucose conversion (70\%) while avoiding intermediate separation steps. Furthermore, in the as-combined steps, the use of an immobilized glucose isomerase and an acidic resin facilitates catalyst recycling.
\end{abstract}

Keywords: (bio) catalysis; biomass; glucose; 5-hydroxymethylfurfural (HMF); chemo-enzymatic catalysis

\section{Introduction}

In a context of the fast depletion of fossil resources, lignocellulosic biomass possesses a high potential as a sustainable raw material for fuels [1] and fine chemicals [2,3] production in industrially significant volumes. Upon specific physical, chemical and/or biological treatments of lignocellulose, access can be gained to monomeric sugars [4] like glucose as its main saccharidic component. Glucose is, as a result, currently considered as one of the most promising starting materials for the conversion of biomass into drop-in or new high-value platform chemicals [5]. 
Efficient and eco-responsible valorization routes for this new renewable carbon source are highly desirable, and every field of catalysis should be mobilized as the key to success for a selective valorization of such a polyfunctional substrate. Biocatalytic processes are already or are about to be industrialized [6] and heterogeneous or homogeneous catalysis, alone or in combination, have shown high efficiency for biomass valorization, but lack of selectivity still causes problems in the products' separation steps [7]. In the last few years, a new paradigm of catalysis has emerged to answer the challenges of selectivity and productivity by combining biocatalysis and chemocatalysis [8-10]. This combination is known as chemo-enzymatic catalysis or hybrid catalysis [11,12].

In the field of sustainable and biosourced chemistry, glucose conversion to 5-hydroxymethylfurfural (HMF) deserves specific attention as a platform molecule [13]. Its hydrogenation, for instance, can lead to 2,5-dimethylfuran (2,5-DMF), a new fuel additive [14] and a precursor of terephthalic acid after dehydrative Diels-Alder reaction with ethylene to $\mathrm{p}$-xylene and subsequent oxidation [15,16]. HMF oxidation is also envisioned to obtain 2,5-furandicarboxylic acid (FDCA), a biosourced alternative to terephthalic acid in polyester plastic production with a high market potential $[17,18]$. Unfortunately, abundant glucose is not the substrate of choice for efficient dehydration to HMF compared to its more expensive fructose isomer. The latter presents a fructofuranose mutamer more prone to dehydration to a furanic ring with lower energetic barriers [19]. Isomerization of glucose to fructose thus appears as a key step that can hardly be circumvented. A well-known transformation of glucose to fructose is the enzymatic glucose isomerization, employed in the industrial production of high-fructose corn syrup "HFCS" [20]. Despite the need for expensive high-purity glucose, for buffers and multiple ion-exchange resins to get rid of all the metallic residues in alimentary HFCS, enzymatic isomerization remains the preferred process compared to chemical isomerization, even if the latter receives a recent renewed interest [21-25]. The aforementioned enzymatic reaction reaches a thermodynamic equilibrium (Keq 1), which limits glucose conversion [26-28]. Whereas this equilibrium is particularly well-adapted for HFCS production involving glucose/fructose mixtures, HMF synthesis requires a pure fructose feed for the subsequent dehydration step, where compatibility issues between catalysts arise: Huang et al. indeed shown incompatibility between a thermophilic glucose isomerase immobilized on aminopropyl-functionalized mesoporous silica (FMS) and a heterogeneous Brønsted acid propylsulfonic-FMS- $\mathrm{SO}_{3} \mathrm{H}$ in a THF: $\mathrm{H}_{2} \mathrm{O}(4: 1 \mathrm{v} / v)$ mixture [29]. Isomerization is carried out at $363 \mathrm{~K}$ to reach $61 \%$ fructose yield, and then the temperature has to be increased to $403 \mathrm{~K}$ to reach a $30 \% \mathrm{HMF}$ yield. In the meantime, glucose isomerase is fully denatured.

Strategies have thus been adopted to combine enzymatic isomerization of glucose to fructose and chemical by separating bio- and chemo-catalysis involving fructose transportation between the isomerization aqueous phase and an organic phase for subsequent reactivity. Huang et al. [30] describe this concept for the first time by adding sodium tetraborate in the aqueous isomerization medium to form a fructoborate compound by complexation with fructose. Transportation of this complex to a separated organic phase is assisted by a cationic quaternary ammonium and enables enhanced glucose conversion by shifting the isomerization equilibrium towards fructose. The separate dehydration of fructose in the organic phase gives an increase in HMF yield up to $63 \%$ compared to a yield of $28 \%$ HMF without borate addition, associated to a glucose conversion of $88 \%$ instead of $53 \%$. However, in this work, the complexation selectivity between glucose and fructose was not satisfactory and was thus further improved by Palkovits et al. who optimized the chemical nature of the complexing boronate species [31]. A global process exploiting this concept for glucose to HMF production has concomitantly been proposed by Alipour et al. [32] Therein, fructose is complexed with phenylboronic acid and transferred to an organic phase, which is separated and contacted with an acidic ionic liquid phase to promote the release of free fructose. This fructose-rich ionic liquid is further used for dehydration to HMF in a biphasic medium. The produced HMF is then back-extracted to a last low-boiling point organic phase. This method involves the use of four different media with intermediate phase separations. Inspired by these sequential processes, we propose here to circumvent this drawback by 
setting up an innovative integrated implementation minimizing the number of steps and preventing, among other things, the use of costly and hard-to-recover ionic liquids.

Herein, we highlight an efficient and fully-integrated cascade reactions process to convert glucose to HMF using an organic liquid membrane separating two aqueous phases for fructose transportation. This approach that we first proposed as a concept exemplifying the potential of hybrid catalysis [33] is based on continuous aqueous glucose isomerization, fructose complexation, extraction and transportation towards an intermediate organic phase. Fructose is then released at the interface with the second aqueous phase (aqueous receiving phase), where it is subsequently dehydrated to HMF. This integrated process without intermediate phase recovery, separation and recycling is presented in Figure 1. Before fully designing the entire process, where all the reactions are carried out simultaneously, we separately investigated each reaction to notably determine their respective optimal ranges of conditions before combination: (1) glucose isomerization to fructose occurs in a primary aqueous feed phase; (2) the as-formed fructose transportation is then made possible through selective complexation with phenylboronic acid as a carrier associated to a quaternary ammonium into an organic solvent (4-methyl-2-pentanone "MIBK"); (3) eventually, the fructoboronate complex is hydrolyzed by acidic conditions in a receiving aqueous phase containing an acidic resin, which also promotes dehydration of fructose to HMF. MIBK was chosen among different solvents, such as methyl-tert-amyl-ether, 5-methyl-2-hexanone, dimethyl carbonate, etc. ... but the study is not presented here. Our criteria were the solubility, toxicity, boiling point. With MIBK and methyl-tert-amyl-ether, we have obtained the best results in terms of fructose extraction yield but we have chosen MIBK $\left(117^{\circ} \mathrm{C}\right)$ due to its higher boiling point than that of methyl-tert-amyl-ether $\left(86^{\circ} \mathrm{C}\right)$. This criterion was important for the implementation of the chemical catalysis step at $80-90{ }^{\circ} \mathrm{C}$. Finally, our approach was not only focused on the compatibility issues of bio- and chemocatalytic reactions with the aim of overcoming the isomerization equilibrium limitation, but also pays particular attention to integrating all the steps to minimize separation and recycling burdens, which can be detrimental for the overall economics and efficiency of the process. The methodology envisioned to move from a sequential approach towards an integrated continuous process is schematized in Figure 2.

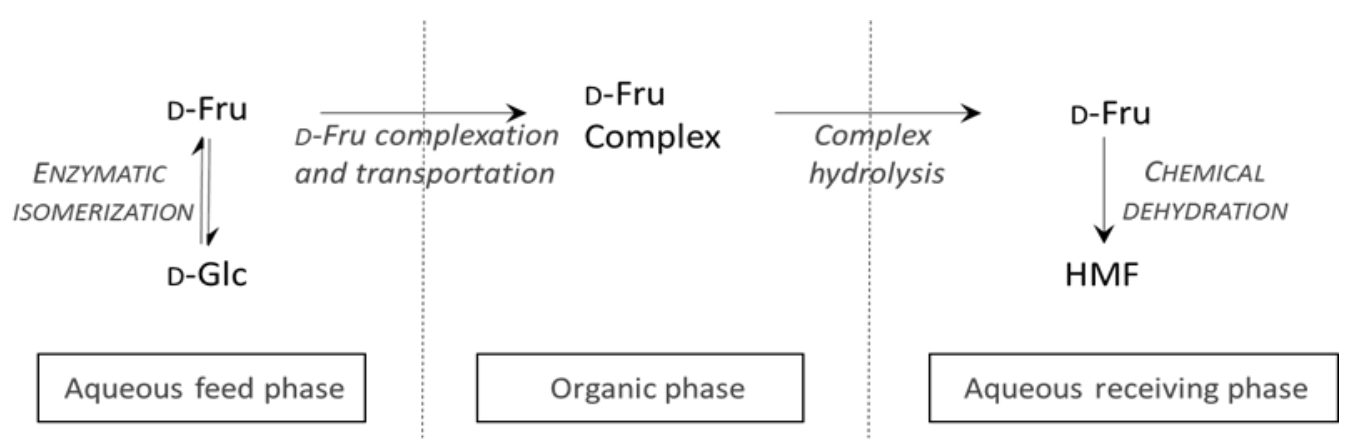

Figure 1. Hybrid catalysis simultaneous process applied to the transformation of glucose to HMF $($ D-Glc $=$ D-glucose, D-Fru $=$ D-Fructose, $\mathrm{HMF}=$ 5-hydroxymethylfurfural $)$. 


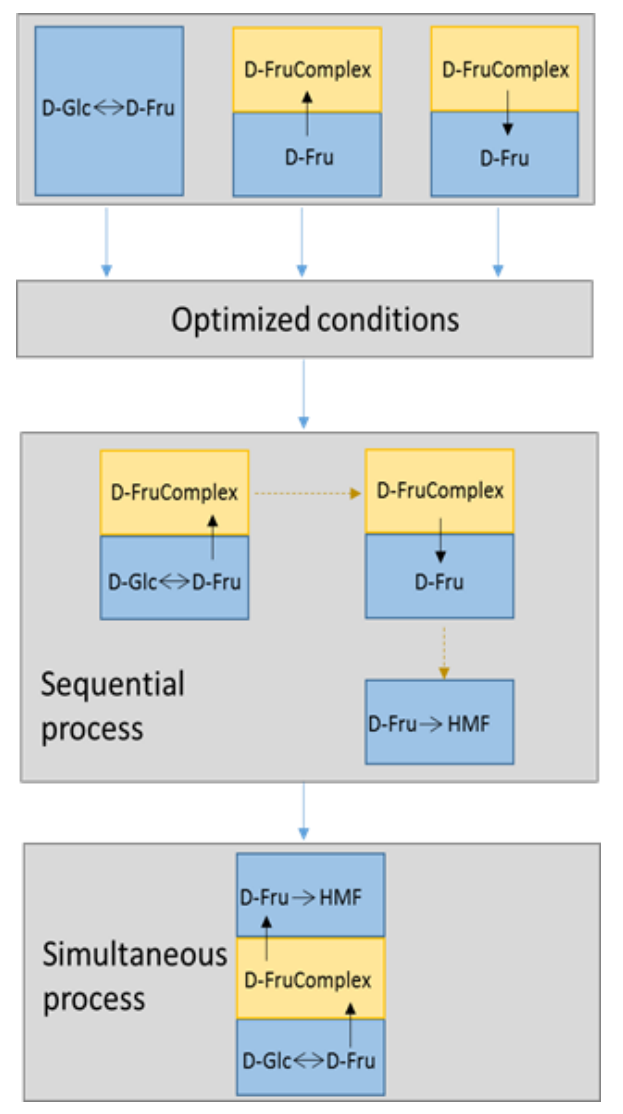

Figure 2. Methodology from a sequential approach towards an integrated continuous process.

\section{Results and Discussion}

\subsection{Study of D-Glucose Enzymatic Isomerization in the Aqueous Feed Phase}

The optimal temperature of use ranges from 333 to $353 \mathrm{~K}$ and the optimum $\mathrm{pH}$ ranges from $\mathrm{pH}$ 7.0 to 9.0 [34]. We first checked the influence of $\mathrm{pH}$ and temperature using the lot of Immobilized Glucose Isomerase (IGI) received from our supplier. A glucose solution at $\mathrm{pH} 7.5$ (Tris-HCl buffer, 100 $\mathrm{mM}$ ) was prepared and isomerized from $323 \mathrm{~K}$ to $363 \mathrm{~K}$. The relative enzymatic activity is presented in Figure 3, which highlights a maximal enzymatic activity at $343 \mathrm{~K}$. A glucose solution of a $\mathrm{pH}$ from 4.5 to 9 (Tris- $\mathrm{HCl}$ buffer, $100 \mathrm{mM}$ from $\mathrm{pH} 7$ to 9; sodium phosphate buffer, $100 \mathrm{mM} \mathrm{pH}$ 6.5; sodium citrate buffer, $100 \mathrm{mM} \mathrm{pH} \mathrm{4.5)} \mathrm{was} \mathrm{thus} \mathrm{prepared} \mathrm{and} \mathrm{isomerized} \mathrm{at} 343 \mathrm{~K}$. The relative enzymatic activity presented in Figure 4 shows a maximal IGI activity at a $\mathrm{pH}$ around 7.5. It is noteworthy that the IGI maintained more than $80 \%$ of its optimal activity between $\mathrm{pH} 7$ and 9 . Below a $\mathrm{pH}$ of 6.5 , the IGI lost more than $50 \%$ of its activity. The $\mathrm{pH}$ and the temperature chosen must both allow the optimal functioning of the enzyme but also promote the extraction phenomenon by maintaining a $\mathrm{pH}$ larger than the $\mathrm{pKa}$ of boronic acid. Indeed, the extraction of D-fructose by formation of a complex [D-fructose-boronic acid] $]^{-}$is favored if the $\mathrm{pH}$ of the aqueous solution containing D-fructose is larger than the pKa of boronic acid [22]. The pKa of the main boronic acids are less than 8.5. In this context, we chose $\mathrm{pH} 8$ that makes it possible to overcome the pKa-related lock of the selected boronic acid to transport fructose to the organic phase while maintaining a relative activity of more than $80 \%$ of IGI. A D-glucose enzymatic isomerization was then performed in the selected conditions (Tris- $\mathrm{HCl} 100$ $\mathrm{mM}, \mathrm{pH} 8.5,343 \mathrm{~K}$ ). The results are presented in Figure 5 as a function of time. A blank reaction (grey dots) was run in the absence of IGI and showed the absence of D-glucose isomerization or degradation in the chosen experimental conditions. When IGI was present in the system, the D-fructose amount increased from $0 \%$ to $42 \%$ during the first $30 \mathrm{~min}$. From 30 to $60 \mathrm{~min}$, the D-glucose conversion was 
slower, while the D-Fructose amount increased from $42 \%$ to $55 \%$. A maximum D-glucose conversion of $55 \%$ was finally reached in agreement with the glucose-fructose thermodynamic equilibrium expected at this temperature $(\mathrm{Keq}=1.23)$, as already observed by McKay et al. [35].

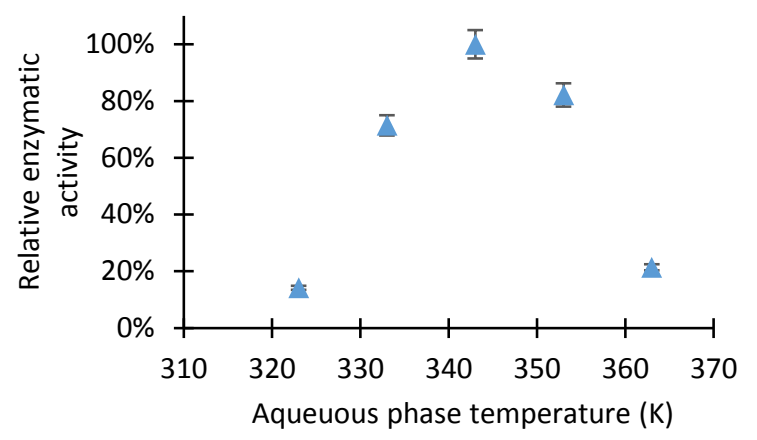

Figure 3. Relative enzymatic activity of IGI in D-glucose isomerization at $\mathrm{pH} 7.5$ as a function of temperature.

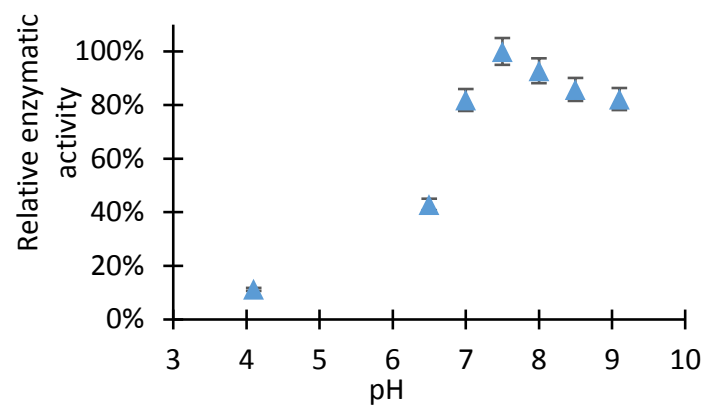

Figure 4. Relative enzymatic activity of IGI in D-glucose isomerization at $343 \mathrm{~K}$ as a function of $\mathrm{pH}$.

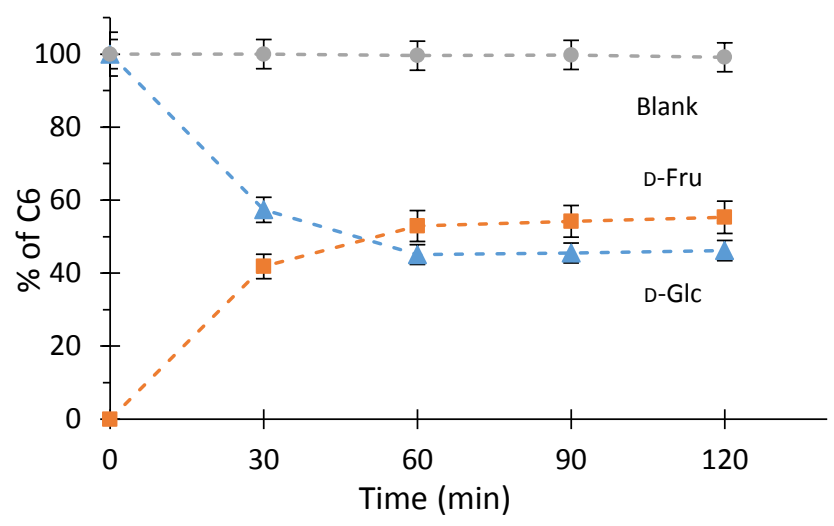

Figure 5. D-glucose consumption during the isomerization step as a function of time; $(\Delta)$, D-fructose formation $(\square)$, D-glucose amount in the blank experiment at $\mathrm{pH} 8.5(\bigcirc)$. Initial conditions: D-Glucose (100 mM), IGI (0.5 g), Tris-HCl 100 mM, pH 8.5, V = 100 mL, 343 K, 750 rpm.

\subsection{Organic Liquid Membrane for D-Fructose Complexation/Transportation}

In order to enhance the isomerization yield, simultaneous isomerization and complexation/transportation of D-fructose in a liquid/liquid aqueous/organic biphasic system was further studied. The temperature was set at $343 \mathrm{~K}$ and the $\mathrm{pH}$ was chosen as a trade-off to simultaneously maximize the enzymatic activity $(7<\mathrm{pH}<9)$; to avoid monosaccharide degradation, and to enhance the extraction process as reported previously [36], the $\mathrm{pH}$ was thus kept at a value of 
8.5 by using a Tris- $\mathrm{HCl} 100 \mathrm{mM}$ buffer. The extraction was conducted in an organic solvent with low water miscibility (MIBK) containing a lipophilic arylboronic acid (carrier) and a quaternary ammonium salt (Aliquat336 ${ }^{\circledR}$ ) as a phase transfer agent [37]. At $\mathrm{pH} 8.5$, aryl boronic acid $\mathrm{ArB}(\mathrm{OH})_{2}$ was actually present under its hydroxylated anionic form, as a tetrahedral aryltrihydroxyborate $\operatorname{ArB}(\mathrm{OH})_{3}{ }^{-}$[38]. At the interface between the aqueous and organic phases, D-fructose further reacts with the arylborate to form a tetrahedral fructoboronate ester (Figure 6) [38]. The fructoboronate complex then forms an intimate ion pair with Aliquat $336^{\circledR}$, which enables its transportation to the organic phase [39].

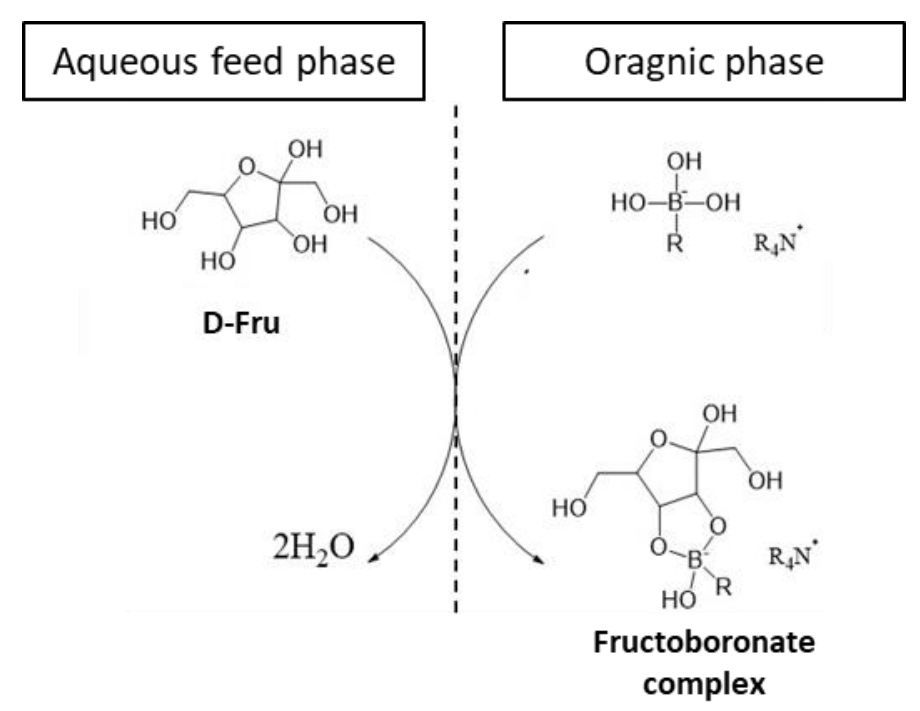

Figure 6. Fructoboronate complex formation at the interphase between the first aqueous phase and the organic liquid membrane.

\subsubsection{Influence of the Boronic Acid Structure}

The influence of the boronic acid structure was investigated in order to optimize kinetics and maximize the selectivity of D-fructose complexation/transportation. Seven arylboronic acids differing by the electronic properties of their substituents and thus by their pKa were screened in the complexation reaction with D-fructose (Figure 7): 2,3-DCPBA, 2,4-DCPBA, 3,4-DCPBA, 3,5-DCPBA, PBA, 4-TBPBA, 4-TFMPBA. The complexation/transportation, which will be referred to as "extraction" in the following sections, was carried out in a biphasic system, as described before. The pKa of the different boronic acids and the relative extraction yields are summarized in Table 1 and reported in Figure 8.<smiles>OB(O)c1ccccc1</smiles>

PBA<smiles>OB(O)c1cccc(Cl)c1Cl</smiles>

2,3-DCPBA<smiles>OB(O)c1ccc(Cl)c(Cl)c1</smiles>

3,4-DCPBA

Figure 7. Cont. 
<smiles>OB(O)c1ccc(C(F)(F)F)cc1</smiles>

$$
\text { 4-TFMPBA }
$$<smiles>CC(C)(C)c1ccc(B(O)O)cc1</smiles>

4-ТВРВА<smiles>OB(O)c1cc(Cl)cc(Cl)c1</smiles>

3,5-DCРBA<smiles>OB(O)c1ccc(Cl)cc1Cl</smiles>

2,4-DCРBA

Figure 7. Structures of the arylboronic acids used for extraction of fructose.

Table 1. Influence of the boronic acid structure on the extraction yield and rate.

\begin{tabular}{cccccc}
\hline Boronic Acid & pKa & $\begin{array}{c}\text { Extraction } \\
\text { Yield \% }\end{array}$ & \multicolumn{3}{c}{$\begin{array}{c}\text { Extraction Rate } \\
\mu \mathbf{m o l} / \mathbf{m i n}\end{array}$} \\
\hline 4-TBPBA & 9.3 & 8.3 & \pm 5.6 & 0.52 & \pm 0.08 \\
PBA & 9.1 & 32.4 & \pm 0.3 & 1.27 & \pm 0.39 \\
2,4-DCPBA & 8.9 & 43.3 & \pm 1.6 & 1.56 & \pm 0.34 \\
3,4-DCPBA & 7.4 & 46.5 & \pm 4.9 & 1.48 & \pm 0.23 \\
2,3-DCPBA & 7.4 & 49,2 & \pm 1.6 & 1.99 & \pm 0.17 \\
4-TFMPBA & 9.1 & 50.3 & \pm 2.2 & 1.26 & \pm 0.12 \\
3,5-DCPBA & 7.4 & 55.3 & \pm 0.9 & 1.94 & \pm 0.20 \\
\hline
\end{tabular}




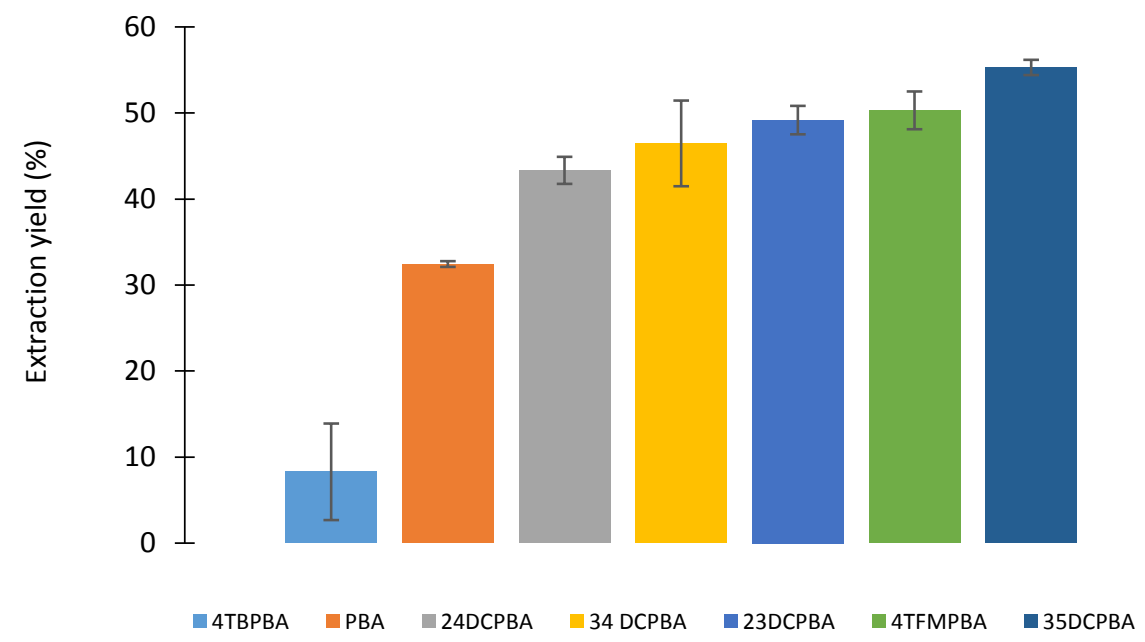

Figure 8. Influence of the arylboronic acid structure on the complexation/transportation process after $45 \mathrm{~min}$. [D-Fructose $]_{\mathrm{i}}=100 \mathrm{mM}$, [Boronic acid] $=100 \mathrm{mM},\left[\right.$ Aliquat $336^{\circledR}$ ] $=200 \mathrm{mM}$, Tris HCl $100 \mathrm{mM}$ pH 8.5, MIBK, $343 \mathrm{~K}, 750 \mathrm{rpm}$.

A group composed by 2,4-DCPBA, 3,4-DCPBA, 2,3-DCPBA, 4TFMPBA and 3,5-DCPBA showed the best results with extraction yields between $43 \%$ and $55 \%$, while with 4 -TBPBA and PBA only $8 \%$ and $32 \%$ were achieved, respectively. These results also show that the D-fructose extraction yield increases when the $\mathrm{pKa}$ of the boronic acid used decreases. Better extraction yields were observed when the $\mathrm{pKa}$ of the boronic acid was lower than (or close to) the $\mathrm{pH}$ of the aqueous feed phase (8.5). This analysis supports the hypothesis from Morin et al. [36] and Karpa et al. [37] indicating that higher extraction yields are obtained when $\mathrm{pH} \geq \mathrm{pKa}$, favoring a predominant tetrahedral anionic borate form of the complex, which enables its transportation by association with the ammonium carrier. An exception was, however, observed with 4-TFMPBA with a pKa of 9.1. This might be due to the fact that 4-TFMPBA has a higher dipolar moment $(2.90 \mathrm{D}$, against $0.43 \mathrm{D}$ to $1.86 \mathrm{D}$ for the other used boronic acids) that could increase the reactivity. The extraction rates and the pKas (Table 1) seem to be correlated. A higher pKa of the boronic acid was linked with a lower initial extraction rate. Among the most effective boronic acids, 3,4-DCPBA was selected for further studies.

\subsubsection{Influence of the Boronic Acid: Aliquat $336^{\circledR}$ Molar Ratio}

With 3,4-DCPBA as the selected boronic acid, the influence of the molar ratio between the boronic acid and the ammonium salt Aliquat $336^{\circledR}$ in the organic solvent was investigated. Figure 9 shows the evolution of D-Fructose concentration in the aqueous phase as a function of time for different Aliquat $336^{\circledR}$ concentrations (from 0 to $400 \mathrm{mM}$ ). D-Fructose and 3,4-DCPBA were initially introduced at concentrations of $100 \mathrm{mM}$. In the first $15 \mathrm{~min}$ of reaction, the concentration of D-Fructose decreased irrespective of the Aliquat $3366^{\circledR}$ concentration with various initial rates. An equilibrium seemed to be progressively reached between 15 and $45 \mathrm{~min}$, as no more evolution of the D-Fructose concentration was then observed. A blank reaction (blue dots) without Aliquat $336{ }^{\circledR}$ nor 3,4-DCPBA was also tested, which showed no evolution. From these observations, it can be considered that the molar ratio 3,4-DCPBA:Aliquat $336^{\circledR}$ is a relevant parameter to control the initial D-fructose extraction rate. Figure 10 shows the evolution of the initial extraction rate and of the D-fructose extraction yield for different 3,4-DCPBA:Aliquat $336^{\circledR}$ molar ratios (from 1:0.5 to 1:4). The initial extraction rate continuously increased when the 3,4-DCPBA:Aliquat336 ${ }^{\circledR}$ molar ratio increased from 1:0.5 to 1:2 with respectively $0.37 \mu \mathrm{mol} / \mathrm{min}$ and $1.50 \mu \mathrm{mol} / \mathrm{min}$. Above a 1:2 molar ratio, no further kinetic benefits could be clearly observed from such an excess of Aliquat $336^{\circledR}$ in the reaction medium. This result is consistent with an ion-pairing phenomenon between the fructoboronate complex and the Aliquat $336^{\circledR}$ occurring at the interphase enabling D-fructose transportation. The D-fructose extraction yield increased when the 
3,4-DCPBA:Aliquat $336{ }^{\circledR}$ molar ratio increased from 1:0.5 to $1: 2$ with respectively $21.5 \%$ and $50.0 \%$. As in the case of the initial extraction rate, above a 1:2 molar ratio no further benefits on the extraction yield were displayed by using an excess of Aliquat $336^{\circledR}$. Therefore, in order to maximize the initial extraction yield and the initial rate while optimizing the quantity of ammonium salt added, an arylboronic acid:Aliquat $336^{\circledR}$ ratio of 1:2 was selected for the following studies.

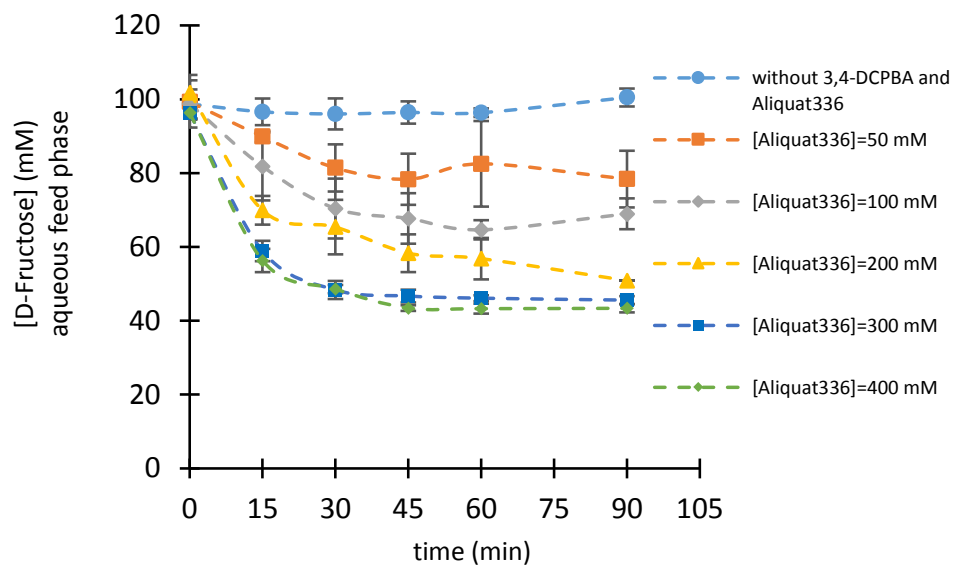

Figure 9. Evolution of [D-fructose] in the aqueous phase as a function of time for different 3,4-DCPBA/Aliquat $336^{\circledR}$ ratios. [D-fructose $]_{\mathrm{i}}=100 \mathrm{mM},[3,4-\mathrm{DCPBA}]=100 \mathrm{mM}$, [Aliquat336 ${ }^{\circledR}$ ] $=\mathrm{X} \mathrm{mM}$ (X varies from 0 to $400 \mathrm{mM}$ ), Tris- $\mathrm{HCl} 100 \mathrm{mM} \mathrm{pH} \mathrm{8.5,} \mathrm{MIBK,} 343 \mathrm{~K}, 750 \mathrm{rpm}$.

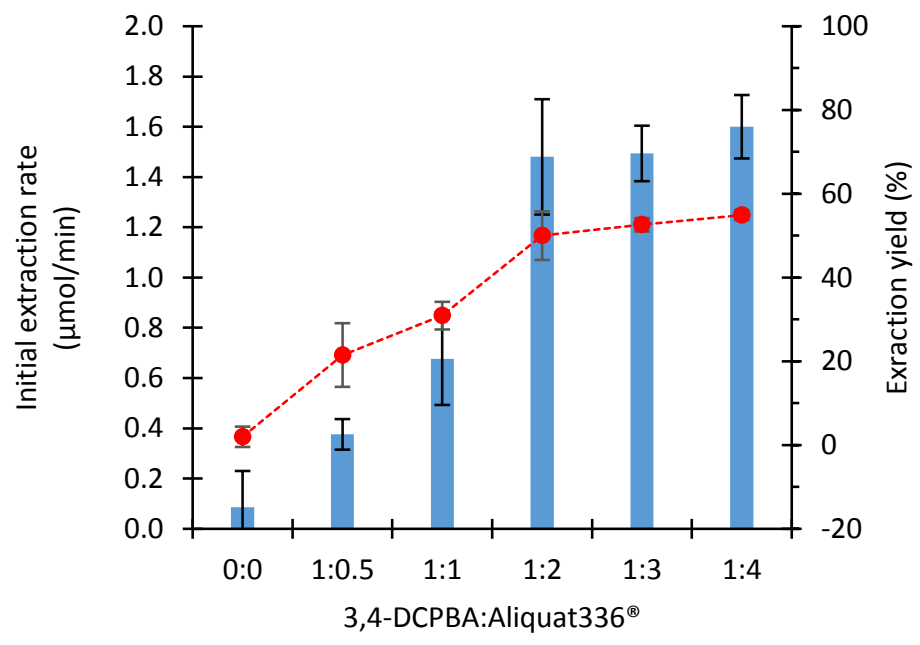

Figure 10. Initial extraction rate in aqueous phase (blue rods) and extraction yield (red dots) in function of 3,4-DCPBA:Aliquat336 ${ }^{\circledR}$ molar ratio. [D-Fructose $]_{\mathrm{i}}=100 \mathrm{mM},[3,4-\mathrm{DCPBA}]=100 \mathrm{mM}$, [Aliquat336 ${ }^{\circledR}$ ] $=\mathrm{X} \mathrm{mM}$ (X varies from 0 to $400 \mathrm{mM}$ ), Tris-HCl $100 \mathrm{mM}, \mathrm{pH}$ 8.5, MIBK, $343 \mathrm{~K}, 750 \mathrm{rpm}$.

\subsubsection{Influence of Boronic Acid and Aliquat $336^{\circledR}$ Concentrations}

Keeping a molar ratio of arylboronic acid: Aliquat $336^{\circledR}$ equal to $1: 2$ and at fixed initial D-Fructose amount, both 3,4-DCPBA and Aliquat $336^{\circledR}$ concentrations were varied, considering the best compromise between component concentrations and costs (Figure 11). From 0 to $15 \mathrm{~min}$, the D-Fructose extraction yield increases rapidly and then stabilizes for lowest 3,4-DCPBA concentrations less than $100 \mathrm{mM}$. The best extraction yields are thus obtained for higher 3,4-DCPBA concentrations, the final yield being the highest at $300 \mathrm{mM}$. The slight difference in extraction yields between 100 $\mathrm{mM}$ and $300 \mathrm{mM}$ 3,4-DCPBA concentration does not justify the use of such a concentrated solution. From Figure 12, the initial extraction rate values for different 3,4-DCPBA:Aliquat336 ${ }^{\circledR}$ concentrations 
have been calculated (Table 2). Two behaviors can be observed, the first one for the 25:50 ratio and the second one for all the other ratios, namely from 50:100 to 300:600. We observed that the larger the 3,4-DCPBA amount, the higher the initial extraction rate. However, after a certain amount of 3,4-DCPBA, the interface seems to be saturated by 3,4-DCPBA:Aliquat $336^{\circledR}$ complexes and then the initial rate does not increase anymore. Therefore, further optimization steps considered a concentration of $100 \mathrm{mM}$ while keeping a molar ratio of 1:2 with Aliquat $336^{\circledR}$.

Table 2. Initial extraction rates for various concentrations in the system. [D-Fructose $]_{i}=100 \mathrm{mM}$, $[3,4-\mathrm{DCPBA}]=\mathrm{Y} \mathrm{mM}(\mathrm{Y}$ varies from 25 to $300 \mathrm{mM})$, [Aliquat $\left.336^{\circledR}\right]=\mathrm{Yx} 2 \mathrm{mM}$, Tris- $\mathrm{HCl} 100 \mathrm{mM}, \mathrm{pH} 8.5$, MIBK, $343 \mathrm{~K}, 750 \mathrm{rpm}$.

\begin{tabular}{ccc}
\hline $\begin{array}{c}{[3,4-D C P B A} \\
(\mathbf{m M})\end{array}$ & \multicolumn{2}{c}{$\begin{array}{c}\text { Extraction Rate } \\
(\boldsymbol{\mu} \mathbf{m o l} / \mathbf{m i n})\end{array}$} \\
\hline 25 & 0.89 & \pm 0.15 \\
50 & 1.37 & \pm 0.41 \\
150 & 1.45 & \pm 0.05 \\
100 & 1.22 & \pm 0.15 \\
200 & 1.40 & \pm 0.21 \\
300 & 1.33 & \pm 0.14 \\
\hline
\end{tabular}

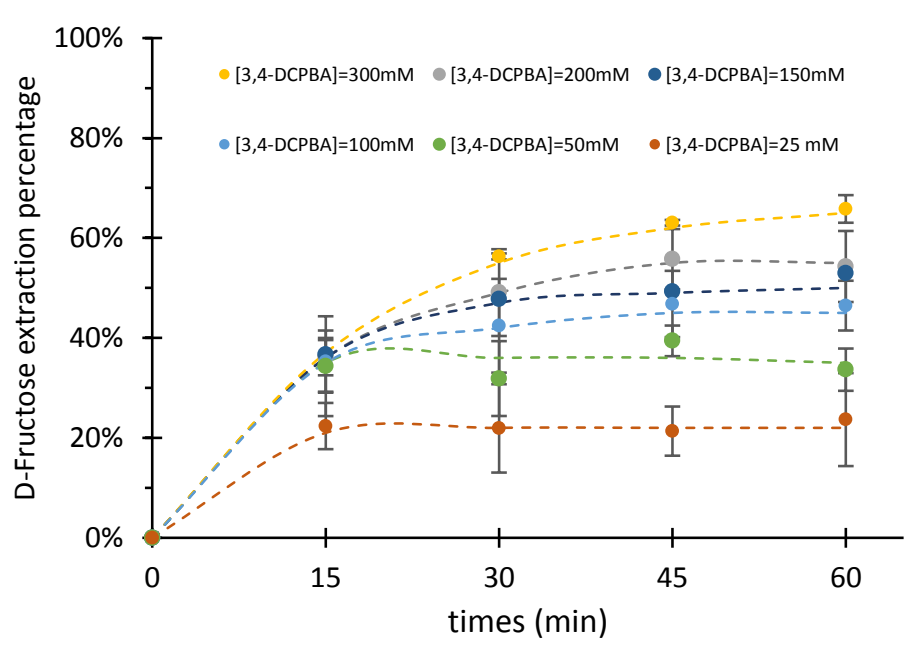

Figure 11. Evolution of the D-Fructose extraction yield for different 3,4-DCPBA and Aliquat336 ${ }^{\circledR}$ concentrations for a 1:2 molar ratio. [D-Fructose $]_{i}=100 \mathrm{mM},[3,4-\mathrm{DCPBA}]=\mathrm{Y} \mathrm{mM}$ (Y varies from 25 to $300 \mathrm{mM}$ ), [Aliquat336 ${ }^{\circledR}$ ] $=\mathrm{Y} \times 2 \mathrm{mM}$, Tris- $\mathrm{HCl} 100 \mathrm{mM}, \mathrm{pH}$ 8.5, MIBK, $343 \mathrm{~K}, 750 \mathrm{rpm}$.

\subsubsection{Influence of the D-Fructose: Boronic Acid Molar Ratio}

The influence of the D-Fructose: 3,4-DCPBA molar ratio was further investigated. Figure 12 shows the D-fructose extraction yield as a function of this molar ratio. The yield ranged between $40 \%$ and $60 \%$, for ratios from $0.25: 1$ to $1: 1$ and between $18 \%$ and $28 \%$ for ratios from $2: 1$ to $10: 1$. When the 3,4-DCPBA was introduced in excess or stoechiometrically compared to D-Fructose (red rods), the extraction yield was larger than $40 \%$, reaching a maximum of $60 \%$ for a two-fold excess of boronic acid. However, when it was introduced in default (blue rods), the extraction yield did not exceed 35\% without any significant further evolution between a molar ratio of 2:1 to 10:1. 


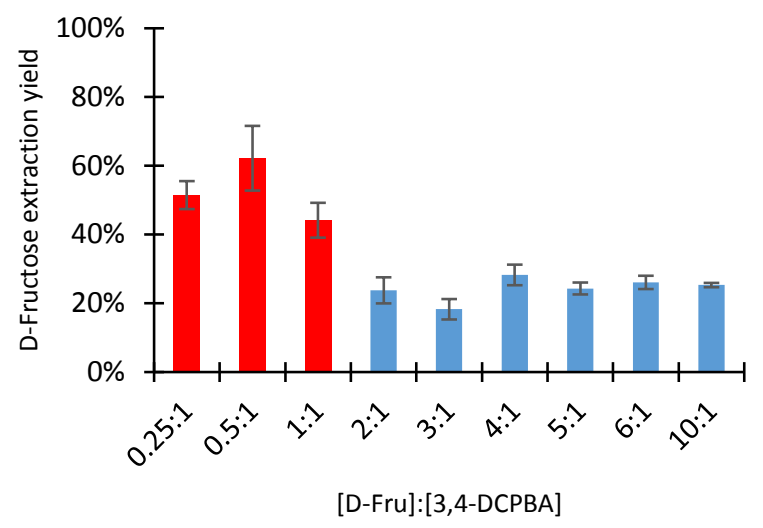

Figure 12. Influence of the initial D-Fructose:3,4-DCPBA molar ratio on the the extraction yield. $[\text { D-Fructose }]_{i}=X \mathrm{mM},[3,4-\mathrm{DCPBA}]=100 \mathrm{mM},\left[\right.$ Aliquat $\left.336^{\circledR}\right]=200 \mathrm{mM}$, Tris- $\mathrm{HCl} 100 \mathrm{mM}, \mathrm{pH} 8.5$, MIBK, $343 \mathrm{~K}, 750 \mathrm{rpm}$.

\subsubsection{Influence of D-fructose and Boronic Acid Concentrations}

The evolution of the extracted D-fructose concentration as a function of the initial D-fructose concentration, for the same 3,4-DCPBA concentration, is shown in Figure 13. Logically, when the initial concentration of D-fructose increased from $25 \mathrm{mM}$ to $1000 \mathrm{mM}$, the extracted concentration linearly increased, according to a straight correlation between the initial amount of D-fructose and the amount of extracted D-fructose. Keeping a molar D-fructose:boronic acid ratio equal to 1:1 and a molar ratio of arylboronic acid:Aliquat336 ${ }^{\circledR}$ equal to 1:2, a benchmark experiment was set up with the following parameters: $\mathrm{T}=34 \mathrm{~K},[\mathrm{D} \text {-Fructose }]_{\mathrm{i}}=100 \mathrm{mM},[3,4-\mathrm{DCPBA}]=100 \mathrm{mM}$, [Aliquat $\left.336^{\circledR}\right]=200 \mathrm{mM}$. The other experiments have been set up by doubling all concentrations. Table 3 presents the extraction yields and initial extraction rates depending on the variation of the initial D-fructose concentration while keeping all the molar ratios relative to 3,4-DCPBA and Aliquat $336^{\circledR}$ as constant. An increase in the concentrations (D-Fructose, 3,4-DCPBA and Aliquat336 ${ }^{\circledR}$ ) led to a decrease in the D-Fructose extraction yield. Indeed, at $100 \mathrm{mM}$ of D-Fructose, $43.3 \%$ of the fructoboronate complex were extracted whereas only $32.7 \%$ and $27.3 \%$ were respectively extracted at $200 \mathrm{mM}$ and $300 \mathrm{mM}$ of D-fructose. Therefore, the optimal conditions ([D-Fru]/[3,4-DCPBA]/[Aliquat336] ratio of 100/100/200 mM) were kept for the following studies.

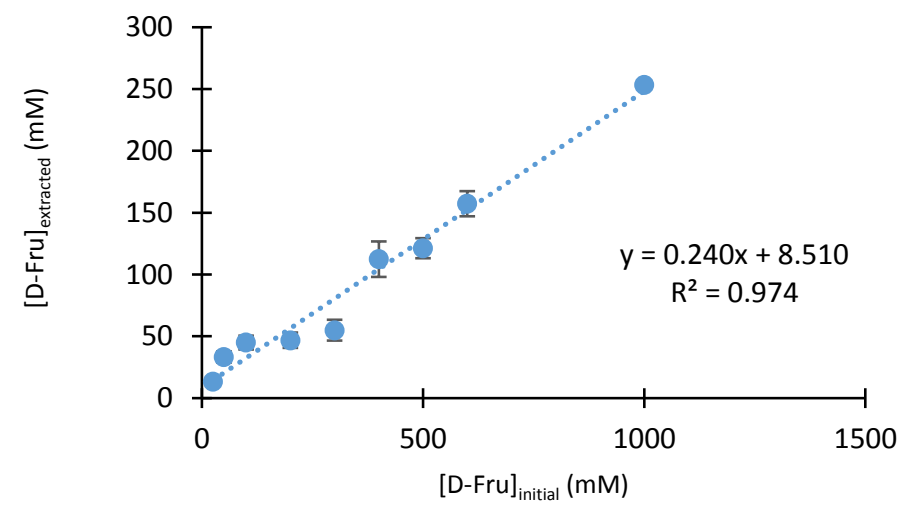

Figure 13. Influence of the initial D-Fructose concentration on the amount of D-fructose extracted. $[\text { D-Fructose }]_{\mathrm{i}}=\mathrm{X} \mathrm{mM}\left(\mathrm{X}\right.$ varies from 25 to 1000), [3,4-DCPBA] $=100 \mathrm{mM}$, [Aliquat $\left.336^{\circledR}\right]=200 \mathrm{mM}$, Tris-HCl 100 mM, pH 8.5, MIBK, 343 K, 750 rpm. 
Table 3. D-fructose extraction yield and initial extraction rate for different concentrations.

\begin{tabular}{ccccc}
\hline $\begin{array}{c}\text { [D-Fru] } \\
\mathbf{m M}\end{array}$ & $\begin{array}{c}\text { [3,4-DCPBA] } \\
\mathbf{m M}\end{array}$ & $\begin{array}{c}\text { [Aliquat336 } \\
\left.{ }^{\circledR}\right] \\
\mathbf{m M}\end{array}$ & \multicolumn{2}{c}{$\begin{array}{c}\text { Extraction Yield } \\
\text { \% }\end{array}$} \\
\hline 100 & 100 & 200 & 43.3 & \pm 4.22 \\
200 & 200 & 400 & 32.6 & \pm 1.22 \\
300 & 300 & 600 & 27.3 & \pm 4.6 \\
\hline
\end{tabular}

2.2.6. Hydrolysis of the Fructoboronate Complex for D-Fructose Release in the Second Aqueous Phase

The further stage of the D-fructose transportation is the fructoboronate complex hydrolysis for D-fructose release in the second aqueous phase (the aqueous receiving phase). This hydrolysis step allows the release of $\mathrm{D}$-fructose in this phase. The influent parameter for the hydrolysis reaction is the $\mathrm{pH}$ of the aqueous solution which will be the "reservoir" of the $\mathrm{H}^{+}$ions necessary for hydrolysis of the fructoboronate complex. Therefore, the influence of the $\mathrm{pH}$ of the second aqueous phase on the release yield was investigated. $\mathrm{pHs}$ of $1,3,5$ and 8 were tested by using with $\mathrm{H}_{2} \mathrm{SO}_{4}$ for $\mathrm{pH} 1$, citrate buffer for $\mathrm{pH} 3$ and 5 and Tris $\mathrm{HCl}$ buffer for $\mathrm{pH} 8$. Prior to these experiments, a D-fructose extraction experiment was performed complexation/transportation in the optimized conditions (100 mM D-fructose and a D-fructose: 3,4-DCPBA:Aliquat336 ${ }^{\circledR}$ molar ratio of 1:1:2). The organic phase was then recovered and contacted with the second aqueous phase for the release step. As observed by Paugam et al. [40] and keeping in mind the final objective of this work that is the obtaining of a simultaneous process, the saccharide flow from the basic aqueous donor phase to the acidic receiving phase through an organic phase is favored when a $\mathrm{pH}$ gradient is applied between the two phases. Figure 14 shows the evolution of the D-fructose release yield as a function of time for different $\mathrm{pH}$ of the aqueous receiving phase. In the cases of $\mathrm{pH} 8$ and $\mathrm{pH} 1$, an increase was observed until 30 min (with an initial rate of about 0.6 and $1.8 \mu \mathrm{mol} / \mathrm{min}$, respectively, Table 4 ) and a steady-state was reached for a yield of $22.7 \%$ and $54.5 \%$ for $\mathrm{pH} 8$ and $\mathrm{pH} 1$, respectively. Concerning $\mathrm{pH} 3$ and $\mathrm{pH} 5$, an increase was observed up to 60 min (with an initial rate of $1.5 \mu \mathrm{mol} / \mathrm{min}$, Figure 14 ) to obtain respectively $91 \%$ and $100 \%$ of release. Considering that the $\mathrm{pKa}$ of 3,4-DCPBA is around 7.4, when the $\mathrm{pH}$ of the receiving aqueous phase is 8 , the $\mathrm{pH}$ is then superior to $\mathrm{pKa}$. Then, the release mechanism is unfavorable [40]. With $\mathrm{pH} 3$ and 5, more than $90 \%$ of the extracted D-Fructose were released. Moreover, the experiment with $\mathrm{H}_{2} \mathrm{SO}_{4}$ at $\mathrm{pH} 1$ shows full hydrolysis of the fructoboronate complex followed by conversion of D-Fructose to HMF, levulinic and formic acid, which explains the high release rate and the decrease in the actual D-fructose concentration after $15 \mathrm{~min}$.

Table 4. Transport yield and extraction rate of D-fructoboronate hydrolysis to D-fructose and D-fructose release in the aqueous phase as a function of its $\mathrm{pH}$.

\begin{tabular}{ccrcr}
\hline $\mathbf{p H}$ & \multicolumn{2}{c}{$\begin{array}{c}\text { Transport Yield } \\
\mathbf{( \% )}\end{array}$} & \multicolumn{2}{c}{$\begin{array}{c}\text { Extraction Rate } \\
(\boldsymbol{\mu} \mathbf{m o l} / \mathbf{m i n})\end{array}$} \\
\hline 5 & 100 & \pm 4.2 & 1.58 & \pm 0.14 \\
3 & 91.5 & \pm 6.3 & 1.53 & \pm 0.13 \\
1 & 54.5 & \pm 3.7 & 1.84 & \pm 0.09 \\
8 & 22.7 & \pm 5.2 & 0.63 & \pm 0.14 \\
\hline
\end{tabular}




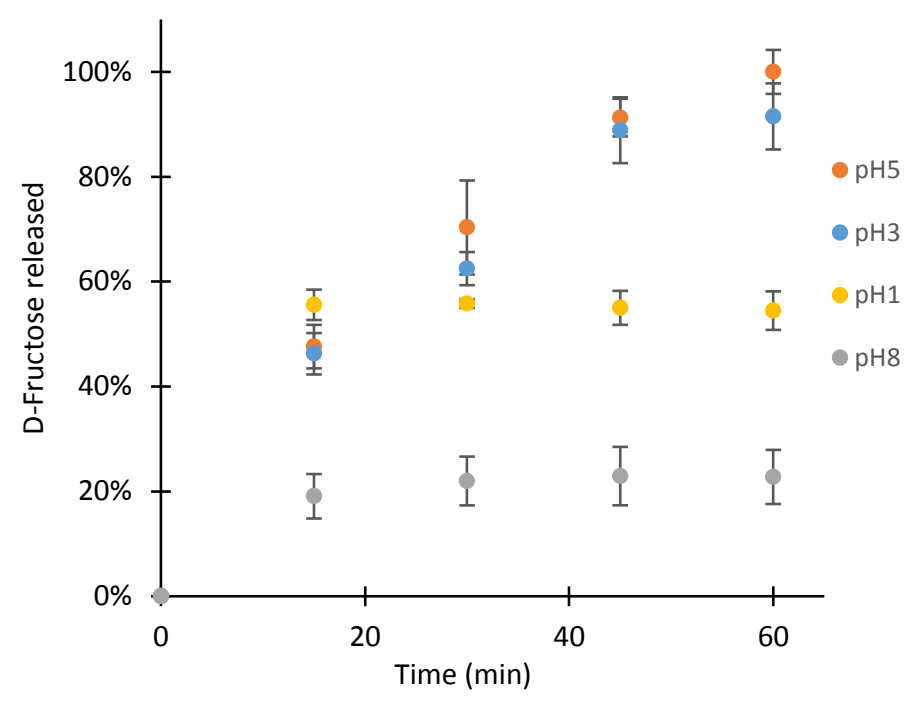

Figure 14. Influence of the $\mathrm{pH}$ of the aqueous receiving phase on the D-fructose complex transportation. Extraction process: Tris- $\mathrm{HCl} 100 \mathrm{mM} \mathrm{pH} \mathrm{8.5,} \mathrm{[D-Fru]}]_{i}=100 \mathrm{mM},[3,4-\mathrm{DCPBA}]=100 \mathrm{mM}$, [Aliquat336 ${ }^{\circledR}$ ] $=200 \mathrm{mM}, \mathrm{MIBK}, 343 \mathrm{~K}$. Receiving phase: Citrate buffer $100 \mathrm{mM} \mathrm{pH} 3$ and 5, Tri-HCl pH 8, H2SO4 for $\mathrm{pH} 1$.

\subsection{Study of D-Fructose Dehydration in the Receiving Aqueous Phase}

D-Fructose dehydration to HMF was carried out in the receiving aqueous phase. We observed previously when studying fructoboronate complex transportation and hydrolysis in a highly acidic aqueous phase the formation of formic and levulinic acids. This confirmed that solutions to minimize HMF degradation by rehydration in the aqueous phase are required. An alternative to strong homogeneous acid has been to use an acidic resin containing strong sulfonic groups. its supported character facilitating a potential regenerability and recyclability of the catalyst. The use of solid acid catalysts prevented the problems of recycling, waste treatment and the risks of use and heating strong acids in liquid form. The type of dehydration catalyst selected for this study was an acidic resin, more particularly a sulfonic resin grafted onto a solid support. Then we have studied the effect of temperature $\left(70^{\circ} \mathrm{C}, 80^{\circ} \mathrm{C}\right.$ and $\left.90^{\circ} \mathrm{C}\right)$ on the yield and the selectivity of the reaction to determine the mass ratio of $\mathrm{H}^{+}$(resin)/D-fructose $(1 / 1,2 / 1$ and 3/1). Finally, we have studied the effect of $\mathrm{pH}$ on the reaction efficiency. The results are not presented because we have logically observed that the HMF yield increases with the increase of temperature and the $\mathrm{H}^{+} / \mathrm{D}$-fructose ratio. However, until $80^{\circ} \mathrm{C}$ no humins are detected but brown colored resin is observed when the temperature is at $90^{\circ} \mathrm{C}$, indicating the formation and adsorption of humins. Therefore, we chose a temperature of $80^{\circ} \mathrm{C}$ and a ratio of $3 / 1$ for the following studies (sequential approach).

\subsection{Study of Sequential Process}

In the formerly optimized conditions, a sequential process was tested. The first step consisted on a simultaneous D-glucose isomerization and D-fructose transportation through a fructoboronate complex, followed by the second step characterized by the hydrolysis of the fructoboronate complex to D-fructose and release of D-fructose in the aqueous receiving phase, and finally by the dehydration of fructose to HMF by heterogeneous catalyst in the third step (Figure 15). 


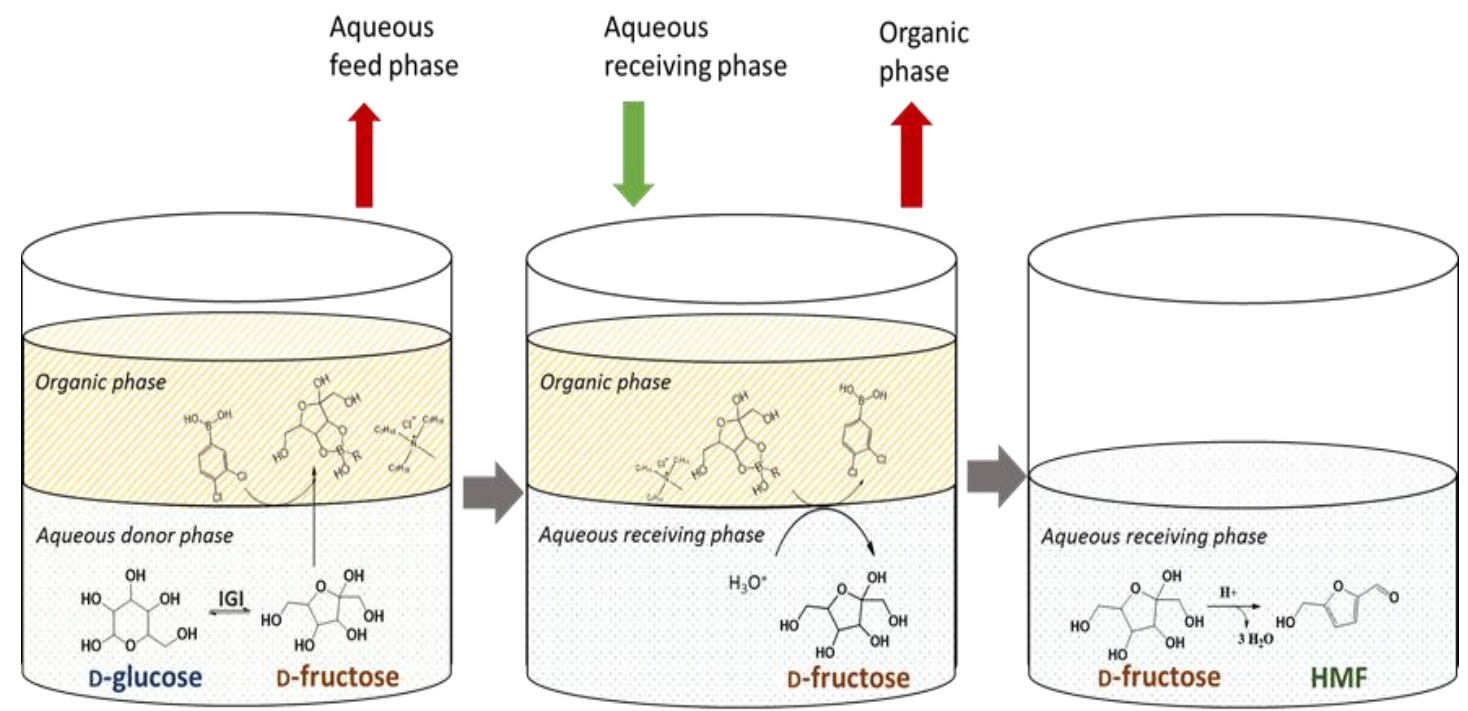

Figure 15. Illustration of the sequential process with isomerization and complexation/transportation step, hydrolysis/release step and dehydration step.

\subsubsection{D-Glucose Isomerization and D-Fructose Complexation/Transportation}

The aqueous feed phase contained Tris-HCl buffer $100 \mathrm{mM}$ at $\mathrm{pH}$ 8.5, D-Glucose and immobilized glucose isomerase at the required amount. The organic layer contained the system determined by the previous study: $[3,4-\mathrm{DCPBA}]=100 \mathrm{mM}$, [Aliquat $\left.336^{\circledR}\right]=200 \mathrm{mM}$. The initial aqueous D-glucose concentration was $100 \mathrm{mM}$. The system was mixed in a reactor where the enzyme was placed in a basket to avoid any contact with the organic layer. Moreover, the use of MIBK, with low solubility in water, as an organic solvent contributed to making the contact between MIBK and enzyme negligible. The system was heated at $343 \mathrm{~K}$ for $3 \mathrm{~h}$. The amount of D-glucose and D-fructose were chromatographically determined in the aqueous phase during the process. Table 5 shows the performance of each step. An interesting isomerization yield of $74.5 \%$ was obtained showing the actual shifting of the equilibrium of the enzymatic catalysis (55\%) by fructose elimination from the media through complexation with the boronic acid. Moreover, according to the extraction yield of D-fructose and D-glucose, $56.5 \%$ and $1 \%$, respectively, a very high selectivity of the complexation reaction with the chosen boronic acid towards the D-fructose was actually demonstrated. The partial D-fructose extraction yield of $56.5 \%$ showed that the reaction conditions could be still improved.

Table 5. Results obtained from sequential process. The D-Fructose released yield was calculated using the amount of D-Fructose in the organic phase at the end of the 1st transport. The fructose conversion yield was calculated using the amount of fructose in the aqueous receiving phase at the end of the 2nd transport. The HMF total amount was calculated using the initial amount of glucose in the aqueous donor phase.

\begin{tabular}{c|ccc|c|cc|c}
\hline \multicolumn{4}{c}{} & \multicolumn{2}{c}{$\mathbf{1}^{\text {st }}$ step } & \multicolumn{2}{c}{ 2 $^{\text {rd }}$ step } \\
\hline & \multirow{2}{*}{ Isomerization } & $\begin{array}{c}\text { D-Fructose } \\
\text { Extracted }\end{array}$ & $\begin{array}{c}\boldsymbol{D} \text {-Glucose } \\
\text { Extracted }\end{array}$ & $\begin{array}{c}\text { D-Fructose } \\
\text { Released }\end{array}$ & $\begin{array}{c}\text { Fructose } \\
\text { Conversion }\end{array}$ & Yield & HMF \\
Total \\
\hline$\%$ \\
time & 74.5 & 56.5 & 1.56 & 57.4 & 52 & 21.9 & 5.3 \\
& & $3 \mathrm{~h}$ & & $3 \mathrm{~h}$ & $35 \mathrm{~h}$ & $41 \mathrm{~h}$ \\
\hline
\end{tabular}




\subsubsection{Fructoboronate Complex Hydrolysis, Release of D-Fructose and Dehydration to HMF}

The basket of IGI was removed and the aqueous feed phase was discarded and replaced by the receiving aqueous phase with a citrate buffer at $100 \mathrm{mM}$ keeping a pH 3 . The system was heated at $343 \mathrm{~K}$ for $3 \mathrm{~h}$. In these conditions, the hydrolysis step led to $63 \%$ of fructose release in the aqueous phase. Then, after $3 \mathrm{~h}$ at $343 \mathrm{~K}$, the organic layer was discarded and the acidic resin was introduced. The system was heated at $363 \mathrm{~K}$. The dehydration step led to a HMF yield of $20 \%$ after $10 \mathrm{~h}$. The total HMF yield was $5 \%$.

\subsection{Study of Continuous Process}

In the best conditions previously determined, a continuous integrated process was tested [33]. The reactor, phases and matter flows are presented in Figure 16. The "coaxial" reactor is composed of two cylinders coaxially placed, a cover enabling introduction of the stirring system and a refrigerant for temperature control. The inner cylinder contains the donor aqueous phase and has a height less than that of the outer cylinder which contains the receiving aqueous phase, which allows the organic phase to be in contact with both aqueous phases. The experiment was conducted with a donor aqueous phase formed by $50 \mathrm{~mL}$ of $100 \mathrm{mM}$ Tris-HCl pH 8.5 containing $100 \mathrm{mM}$ of D-glucose, $200 \mathrm{mg}$ IGI, $20 \mathrm{mM}$ $\mathrm{MgSO}_{4}, 8 \mathrm{mM} \mathrm{Na}_{2} \mathrm{SO}_{3}$. The receiving aqueous phase was formed by $55 \mathrm{~mL}$ of $100 \mathrm{mM}$ sodium citrate buffer, $\mathrm{pH}$ 3. The organic phase consisted of $100 \mathrm{~mL}$ of MIBK containing $100 \mathrm{mM}$ of 3,4-DCPBA and $200 \mathrm{mM}$ of Aliquat $336^{\circledR}$. All the phases were maintained at $343 \mathrm{~K}$. The stirring was carried out at 180 $\mathrm{rpm}$, which is the maximum rate to avoid the mixing of the phases, thanks to a stirring blade immersed in the organic phase. This "coaxial" reactor was used to simultaneously perform the isomerization, extraction, hydrolysis and dehydration steps. The monitoring of the D-fructose concentration in the aqueous phases was carried out, making it possible to calculate the efficiency of the continuous process for the simultaneous isomerization, fructose extraction and dehydration. The results are shown in Table 6.

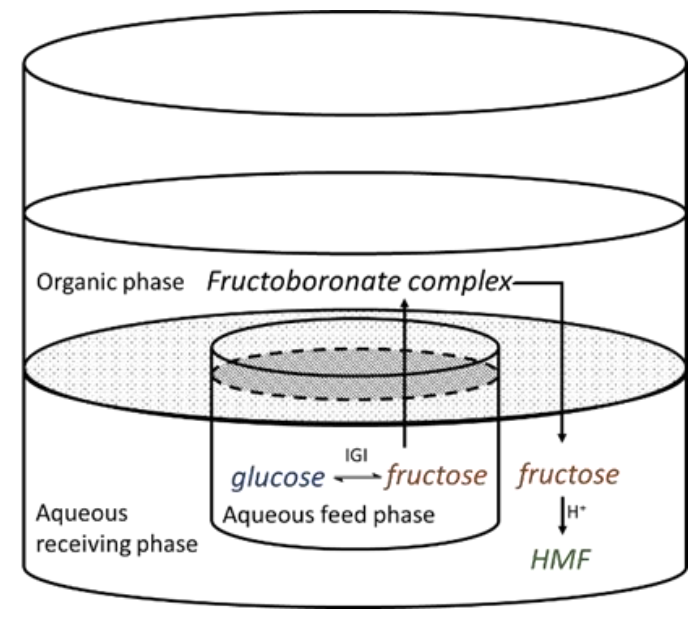

Figure 16. Illustration of the continuous process.

Table 6. Results obtained by continuous process.

\begin{tabular}{ccccc}
\hline & Isomerization & $\begin{array}{c}\text { Fructose } \\
\text { Extraction }\end{array}$ & HMF & Selectivity \\
\hline Yield (\%) & 70.1 & 50.2 & 4.1 & 70.4 \\
\hline
\end{tabular}

The D-glucose isomerization yield was 70\%, with $50 \%$ of the formed D-fructose transported and a global HMF yield of $4 \%$ (Table 6). Those results are comparable to those obtained by the sequential 
process. Therefore, this process demonstrates the efficiency of using a cascade chemo-enzymatic catalysis to continuously obtain HMF from D-glucose. However, insufficient agitation of each phase seems to be the main limitation of this reactor configuration. Further improvements of this proof of concept towards enhanced HMF yields and global performances will be reported in due course.

\section{Materials and Methods}

\subsection{Chemicals and Reagents}

D-Glucose $(\geq 99.5 \%), \quad$ D-Fructose $(\geq 99 \%), \quad N$-methyl- $N, N, N$-trioctylammonium chloride (Aliquat336 $\left.{ }^{\circledR}\right)$, 3,4-dichlorophenylboronic acid (3,4-DCPBA), 3,5-dichlorophenylboronic acid (3,5-DCPBA) (98\%), 2,4-dichlorophenylboronic acid (2,4-DCPBA), 2,3-dichlorophenylboronic acid (2,3-DCPBA), 4-tert-butylphenylboronic acid (4-TBPBA) ( $\geq 95 \%$ ), 4-(trifluoromethyl)phenylboronic acid (4-TFMPBA), Trizma base ( $\geq 99.9 \%$ ), hydrochloric acid (36.8-38\%), sulfuric acid (95-97\%), Sweetzyme IT $^{\circledR}$ Extra (IGI) ( $\geq 350$ U/g), Dowex monosphere 650C, levulinic acid (LA) $(98 \%)$, formic acid (FA) $(95 \%)$, trisodium citrate ( $\geq 99 \%)$, 5-hydroxymethylfurfural (HMF) (99\%) were purchased from Sigma Aldrich Co. (St. Louis, MO, USA). Phenylboronic acid (PBA) (95\%) and 4-methyl-2-pentanone (MIBK) ( $\geq 99 \%)$ were purchased from Sigma-Fluka (Sigma-Aldrich, St. Louis, MO, USA). Citric acid ( $\geq 99 \%)$ was purchased from Merck (Merck KGaA, Darmstadt, Germany). Distilled-deionized water (Mili-Q) grad was used whenever necessary, obtained from a MilliQ water purification system (Millipore, Molsheim, France).

\subsection{Statistical Analysis}

The experiments were performed in triplicate each time. The standard deviation for each experimental result was calculated using Microsoft Excel and reported. The standard deviation for each value was $\leq 5 \%$.

\subsection{Characterization}

In the conversion/complexation experiments, the determination of reactants, intermediates and products quantities was carried out using a Shimadzu high-performance liquid chromatography (HPLC) (Shimadzu Europa, Duisburg, Germany) instrument equipped with a LC-20ADXR pump, a DGU-20A5R degasser, a SIL-20ACXR autosampler, a SPD-MD20A diode array detector, a CTO-20AC oven and a CBM-20A communicator module piloted by a LabSolution software (LC Driver Ver1.0, Shimadzu Europa, Duisburg, Germany). The column was an Aminex HPX-87H (300 mm $\times 7.8 \mathrm{~mm}$, 9 $\mu \mathrm{m}$; Bio-Rad, Hercules, CA, USA). The mobile phase was $5 \mathrm{mM} \mathrm{H}_{2} \mathrm{SO}_{4}$, using isocratic mode with 0.4 mL.min-1. The chosen wavelength for HMF and levulinic acid detection were $284 \mathrm{~nm}$ and $266 \mathrm{~nm}$, respectively. The chosen wavelength for detection of formic acid, D-Glucose and D-Fructose was 195 $\mathrm{nm}$. In the case of monosaccharides, a refractive index detector was also used.

\subsection{Aqueous Phase D-Glucose Isomerization (Aqueous Feed Phase) and D-Fructose Complexation/Transportation}

\subsubsection{D-Glucose Isomerization in Aqueous Feed Phase}

We used one of the commercial enzymes most commonly used for the conversion of starches to high fructose syrup, namely immobilized glucose isomerase (IGI, Sweetzyme ${ }^{\circledR}$ IT extra) [31]. D-glucose solution $(1 \mathrm{~mL})$ was prepared by mixing D-glucose $(100 \mathrm{mM}), \mathrm{Na}_{2} \mathrm{SO}_{3}(8 \mathrm{mM})$ and $\mathrm{MgSO}_{4}(20 \mathrm{mM})$ in a buffer solution $(100 \mathrm{mM}$ ) at a selected $\mathrm{pH}$ (Tris-HCl buffer for $\mathrm{pH} 7,7.5,8,8.5,9$, phosphate buffer for $\mathrm{pH} 6.5$, or citrate buffer for $\mathrm{pH} 4.5$ ) and then introduced in an Eppendorf tube. The solution was incubated at the desired temperature (323 to $363 \mathrm{~K}$ ) in a Mixing Block (BIOER-102 Thermocell) at 900 $\mathrm{rpm}$. After rehydration in water for $12 \mathrm{~h}$, IGI $(10 \mathrm{mg})$ was put in contact with the aforementioned prepared D-glucose solution. The reaction time was set at $90 \mathrm{~min}$. 


\subsubsection{D-Fructose Transport in the Organic Phase}

First, a D-fructose/D-glucose (25 to $600 \mathrm{mM}$ ) solution was prepared in Tris- $\mathrm{HCl}$ buffer $(100 \mathrm{mM})$. A volume $(600 \mu \mathrm{L})$ of this solution was introduced in an Eppendorf tube (solution 1). Aliquat $336^{\circledR}$ (25-300 $\mathrm{mM})$, and arylboronic acid $(25-300 \mathrm{mM})$ were dissolved in MIBK as a solvent to prepare solution 2. Then, $600 \mu \mathrm{L}$ of the solution 2 were introduced in a second Eppendorf tube. Solutions 1 and 2 were incubated at the desired temperature in a mixing block (BIOER-102 Thermocell) at $750 \mathrm{rpm}$. After $5 \mathrm{~min}$, both solutions were mixed in an Eppendorf tube placed in the Mixing Block in the same conditions. After D-fructose transport, the aqueous and organic phases were separated by pipetting.

\subsubsection{Aqueous Phase D-Fructose Complex Hydrolysis in Receiving Aqueous Phase}

Citrate buffer $(600 \mu \mathrm{L})$ were introduced in an Eppendorf tube and incubated at the required temperature $(343 \mathrm{~K})$ in a mixing block at $750 \mathrm{rpm}$. After $5 \mathrm{~min}, 600 \mu \mathrm{L}$ of the organic phase obtained after the extraction procedure and containing the fructoboronate complex were introduced in the tube. After a reaction time of $45 \mathrm{~min}$, the aqueous and organic phases were separated by pipetting.

\subsubsection{Study of Sequential Process from Glucose Isomerization to Fructose Dehydration}

A $250 \mathrm{~mL}$ vessel (Reactor-ReadyTM Lab Reactor, Radley, Figure 15) equipped with a temperature control system (Ministat, Huber temperature control system, HUBER, Chippenham, UK) was used for these experiments.

- Simultaneous D-glucose isomerization by enzymatic catalysis in the aqueous feed phase and D-fructose complexation/transportation in the organic phase.

IGI $(0.5 \mathrm{~g})$ was loaded in a stirring basket introduced in a first reactor (Figure 15-left) with $100 \mathrm{~mL}$ of a aqueous solution containing D-Glucose (100 mM), $\mathrm{Na}_{2} \mathrm{SO}_{4}(8 \mathrm{mM}), \mathrm{MgCl}_{2}(20 \mathrm{mM})$, in Tris-HCl buffer $(100 \mathrm{mM}, \mathrm{pH} 8.5)$ at $343 \mathrm{~K}$. Then, $100 \mathrm{~mL}$ of MIBK containing 3,4-DCPBA $(100 \mathrm{mM})$ and Aliquat $336^{\circledR}$ $(200 \mathrm{mM})$ were introduced in the reactor. The mixture was stirred via the stirring basket at $200 \mathrm{rpm}$, with the temperature kept at $343 \mathrm{~K}$ for $180 \mathrm{~min}$, before discarding the aqueous feed phase.

- D-fructose complex hydrolysis in the aqueous receiving phase.

The organic phase $(100 \mathrm{~mL})$ issued from the first reactor and containing the fructoboronate complex were transferred in a second reactor (Figure 15-middle) and heated at $343 \mathrm{~K}$. Then, $100 \mathrm{~mL}$ of a citrate buffer solution $(100 \mathrm{mM}, \mathrm{pH} 3)$ were introduced. The mixture was stirred with a turbine stirring shaft at $200 \mathrm{rpm}$ and set up at $343 \mathrm{~K}$ for $180 \mathrm{~min}$.

\section{Conclusions}

In this work, we have first provided the conditions of the key parameters (temperature, $\mathrm{pH}$, arylboronic acid structure and concentrations, Aliquat $336{ }^{\circledR}$ concentrations) applied for a sequential process from glucose to HMF through fructose transportation in an organic liquid membrane. The best conditions have been then applied to an unprecedented integrated process in a specifically designed reactor. Therein, enzymatic glucose isomerization and fructose dehydration to HMF, involving an intermediate fructose transportation by complexation with an aryboronic acid-Aliquat $3366^{\circledR}$ complex, could be carried out simultaneously in independent aqueous phases. These phases were both in contact with a single organic phase enabling the transportation of fructose from the first aqueous phase to the second. In this process, we thus succeeded in simultaneously enzymatically isomerizing glucose to fructose and dehydrating fructose to HMF by minimizing the number of reaction media and separation steps. Indeed, no intermediate product or phase isolation was necessary. The use of numerous organic solvents or ionic liquid, as previously described in the literature, is limited to a unique organic phase used for fructose transportation. Improvement of performances in terms of HMF 
yields implying better diffusion of species between the different phases by improving the conception of new reactor systems will be reported in due course.

Author Contributions: Conceptualization, Alexandra Gimbernat and Marie Guehl; Methodology, Nicolas Lopes Ferreira and Egon Heuson; Validation, Rénato Froidevaux, Jean-Sébastien Girardon and Damien Delcroix; Formal Analysis, Mickael Capron and Pascal Dhulster; Investigation, Alexandra Gimbernat and Marie Guehl; Data Curation, Franck Dumeignil; Writing-Original Draft Preparation, Alexandra Gimbernat and Marie Guehl; Supervision, Rénato Froidevaux, Jean-Sébastien Girardon and Damien Delcroix.

Funding: This research received no external funding.

Acknowledgments: This research was funded by IFP Energies nouvelles for funding these studies. Chevreul Institute (FR 2638), Ministère de l'Enseignement Supérieur et de la Recherche, Région Hauts-de-France (CPER ALIBIOTECH), REALCAT platform ('Future Investments' program (PIA), with the contractual reference 'ANR-11-EQPX-0037') and FEDER are acknowledged for supporting and funding partially this work.

Conflicts of Interest: The authors declare no conflict of interest.

\section{References}

1. Nanda, S.; Mohammad, J.; Reddy, S.N.; Kozinski, J.A.; Dalai, A.K. Pathways of lignocellulosic biomass conversion to renewable fuels. Biomass Convers. Biorefin. 2014, 4, 157-191. [CrossRef]

2. Besson, M.; Gallezot, P.; Pinel, C. Conversion of Biomass into Chemicals over Metal Catalysts. Chem. Rev. 2014, 114, 1827-1870. [CrossRef] [PubMed]

3. Aresta, M.; Dibenedetto, A.; Dumeignil, F. Biorefinery: From Biomass to Chemicals and Fuels, 3rd ed.; De Gruyter: Berlin, Germany, 2012; ISBN 978-3-11-026023-6.

4. Agbor, V.B.; Cicek, N.; Sparling, R.; Berlin, A.; Levin, D.B. Biomass pretreatment: Fundamentals toward application. Biotechnol. Adv. 2011, 29, 675-682. [CrossRef] [PubMed]

5. Bozell, J.J.; Petersen, G.R. Technology development for the production of biobased products from biorefinery carbohydrates-The USA Department of Energy's “Top 10" revisited. Green Chem. 2010, 12, 539-545. [CrossRef]

6. Van Heerden, C.D.; Nicol, W. Continuous succinic acid fermentation by Actinobacillus succinogenes. Biochem. Eng. J. 2013, 73, 5-11. [CrossRef]

7. Girard, E.; Delcroix, D.; Cabiac, A. Catalytic conversion of cellulose to $C_{2}-C_{3}$ glycols by dual association of a homogeneous metallic salt and a perovskite-supported platinum catalyst. Catal. Sci. 2016, 6, 5534-5542. [CrossRef]

8. Shanks, B.H. Unleashing Biocatalysis/Chemical Catalysis Synergies for Efficient Biomass Conversion. ACS Chem. Biol. 2007, 2, 533-535. [CrossRef] [PubMed]

9. Vennestrøm, P.N.R.; Taarning, E.; Christensen, C.H.; Pedersen, S.; Grunwaldt, J.D.; Woodley, J.M. Chemoenzymatic Combination of Glucose Oxidase with Titanium Silicalite-1. Chem CatChem 2010, 2, 943-945. [CrossRef]

10. Denard, C.A.; Hartwig, J.F.; Zhao, H. Multistep One-Pot Reactions Combining Biocatalysts and Chemical Catalysts for Asymmetric Synthesis. ACS Catal. 2013, 3, 2856-2864. [CrossRef]

11. Dumeignil, F. Public Serv. Rev. Eur. Union 2011, 22, 528.

12. Dumeignil, F. Chemical Catalysis and Biotechnology: From a Sequential Engagement to a One-Pot Wedding. Chem. Ing. Tech. 2014, 86, 1496-1508. [CrossRef]

13. Van Putten, R.; Van der Waal, J.C.; de Jong, E.; Rasrendra, C.B.; Heeres, H.G.; de Vries, J.G. Hydroxymethylfurfural, A Versatile Platform Chemical Made from Renewable Resources. Chem. Rev. 2013, 113, 1499-1597. [CrossRef] [PubMed]

14. Moliner, M.; Román-leshkov, Y.; Davis, M.E. Tin-containing zeolites are highly active catalysts for the isomerization of glucose in water. Proc. Natl. Acad. Sci. USA 2010, 107, 6164-6168. [CrossRef] [PubMed]

15. Pacheco, J.J.; Davis, M.E. Synthesis of terephthalic acid via Diels-Alder reactions with ethylene and oxidized variants of 5-hydroxymethylfurfural. Proc. Natl. Acad. Sci. USA 2014, 111, 8363-8367. [CrossRef] [PubMed]

16. Lin, Z.; Nikolakis, V.; Ierapetritou, M. Alternative Approaches for p-Xylene Production from Starch: Techno-Economic Analysis. Ind. Eng. Chem. Res. 2014, 53, 10688-10699. [CrossRef]

17. De Jong, E.; Dam, M.A.; Sipos, L.; Gruter, G. Furandicarboxylic Acid (FDCA), a Versatile Building Block for a Very Interesting Class of Polyesters. Am. Chem. Soc. 2012, 1, 1-13. 
18. Boisen, A.; Christensen, T.B.; Fu, W.; Gorbanev, Y.Y.; Hansen, T.S.; Jensen, J.S.; Klitgaard, S.K.; Pedersen, S.; Riisager, A.; Stahlberg, T.; et al. Process Integration for the Conversion of Glucose to 2,5-Furandicarboxylic Acid. Chem. Eng. Res. Des. 2009, 87, 1318-1327. [CrossRef]

19. Akien, G.R.; Qi, L.; Horvath, I.T. Molecular mapping of the acid catalysed dehydration of fructose. Chem. Commun. 2012, 48, 5850-5852. [CrossRef] [PubMed]

20. Parker, K.; Salas, M.; Nwosu, V.C. High fructose corn syrup: Production, uses and public health concerns Biotechnol. Mol. Biol. Rev. 2010, 5, 71-78.

21. Li, H.; Yang, S.; Saravanamurugan, S.; Riisager, A. Glucose Isomerization by Enzymes and Chemo-catalysts: Status and Current Advances. ACS Catal. 2017, 7, 3010-3029. [CrossRef]

22. Delidovich, I.; Palkovits, R. Catalytic Isomerization of Biomass-Derived Aldoses: A Review. ChemSusChem 2016, 9, 547-561. [CrossRef] [PubMed]

23. Choudhary, V.; Pinar, A.B.; Lobo, R.F.; Vlachos, D.G.; Sandler, S.I. Comparison of Homogeneous and Heterogeneous Catalysts for Glucose-to-Fructose Isomerization in Aqueous Media. ChemSusChem 2013, 6 , 2369-2376. [CrossRef] [PubMed]

24. Marianou, A.A.; Michailof, C.M.; Pineda, A.; Iliopoulou, E.F.; Triantafyllidis, K.S.; Lappas, A.A. Glucose to Fructose Isomerization in Aqueous Media over Homogeneous and Heterogeneous Catalysts. ChemCatChem 2016, 8, 1100-1110. [CrossRef]

25. Zhao, S.; Guo, X.; Bai, P.; Lv, L. Catalytic Isomerization of Biomass-Derived Aldoses: A Review. Asian J. Chem. 2014, 26, 4537-4542.

26. Demerdash, M.; Attia, R.M. Equilibrium kinetics of D-glucose to D-fructose isomerization catalyzed by glucose isomerase enzyme from Streptomyces phaeochromogenus. Zentralbl. Mikrobiol. 1992, 147, 297-303. [CrossRef]

27. Gaily, M.H.; Elhassan, B.M.; Abasaeed, A.E.; Al-shrhan, M. Isomerization and Kinetics of Glucose into Fructose. Int. J. Eng. Technol. 2010, 10, 1-6.

28. Takasaki, Y. Kinetic and Equilibrium Studies on D-Glucose-D-Fructose Isomerization Catalyzed by Glucose Isomerase from Streptomyces sp. Agric. Biol. Chem. 1967, 31, 309-313. [CrossRef]

29. Huang, H.; Denard, C.A.; Alamillo, R.; Crisci, A.J.; Miao, Y.; Dumesic, J.A.; Scott, S.L.; Zhao, H. Tandem Catalytic Conversion of Glucose to 5-hydroxymethylfurfural with an Immobilized Enzyme and a Solid Acid. ACS Catal. 2014, 4, 2165-2172. [CrossRef]

30. Huang, R.; Qi, W.; Su, R.; He, Z. Integrating Enzymatic and Acid Catalysis to Convert Glucose into 5-Hydroxymethylfurfural. Chem. Commun. (Camb.) 2010, 46, 1115-1125. [CrossRef] [PubMed]

31. Delidovich, I.; Palkovits, R. Fructose production via extraction-assisted isomerization of glucose catalyzed by phosphates. Green Chem. 2016, 18, 5822-5830. [CrossRef]

32. Alipour, S.; Relue, P.A.; Viamajala, S.; Varanasi, S. High yield 5-(hydroxylmethyl)furfural Production from Biomass Sugars under Facile Reaction Conditions: A Hybrid Enzyme- and Chemo-Catalytic Technology. Green Chem. 2016, 18, 4990-5002. [CrossRef]

33. Gimbernat, A.; Guehl, M.; Capron, M.; Lopes-Ferreira, N.; Froidevaux, R.; Girardon, J.S.; Dhulster, P.; Delcroix, D.; Dumegnil, F. Hybrid Catalysis: A Suitable Concept for the Valorization of Biosourced Saccharides to Value-Added Chemicals. Chem CatChem 2017, 9, 2080-2888. [CrossRef]

34. Bhosale, S.H.; Rao, M.B.; Deshpande, V.V. Molecular and Industrial Aspects of Glucose Isomerase. Microbiol. Rev. 1996, 60, 280-290. [PubMed]

35. McKay, G.; Tavlarides, T. Enzymatic isomerization kinetics of D-Glucose to D-Fructose. J. Mol. Catal. 1979, 6, 57-65. [CrossRef]

36. Morin, G.T.; Paugam, M.F.; Hughes, M.P.; Smith, B.D. Boronic Acids Mediate Glycoside Transport through a Liquid Organic Membrane via Reversible Formation of Trigonal Boronate Esters. J. Org. Chem. 1994, 59, 2724-2730. [CrossRef]

37. Karpa, M.J.; Duggan, P.J.; Griffin, G.J.; Freudigmann, S.J. Competitive Transport of Reducing Sugars Through a Lipophilic Membrane Facilitated by Aryl Boron Acids. Tetrahedron 1997, 53, 3669-3676. [CrossRef]

38. Westmark, P.R.; Gardiner, S.J.; Smith, B.D. Selective Monosaccharide Transport through Lipid Bilayers using Boronic Acid Carriers. J. Am. Chem. Soc. 1996, 118, 11093-11100. [CrossRef] 
39. Shinbo, T.; Nishimura, K.; Yamaguchi, T.; Sugiura, M. Uphill Transport of Monosaccharides across an Organic Liquid Membrane. J. Chem. Soc. Chem. Commun. 1986, 349-358. [CrossRef]

40. Paugam, M.; Riggs, J.A.; Smith, B.D. High fructose syrup production using fructose-selective liquid membranes. Chem Comm 1996, 22, 2539-2540. [CrossRef] 